\title{
ANALISIS KAPASITAS SALURAN DRAINASE DI KECAMATAN KELAPA GADING
}

\author{
Stefanus Andrew Kartawijaya ${ }^{1}$, Arianti Sutandi ${ }^{2}$, dan Vittorio Kurniawan ${ }^{3}$ \\ ${ }^{1}$ Program Studi Sarjana Teknik Sipil, Universitas Tarumanagara, Jl. Letjen S. Parman No.1 Jakarta \\ Stefanus.325160196@stu.untar.ac.id \\ ${ }^{2}$ Program Studi Sarjana Teknik Sipil, Universitas Tarumanagara, Jl. Letjen S. Parman No.1 Jakarta \\ Arianti@ft.untar.ac.id \\ ${ }^{3}$ Program Studi Sarjana Teknik Sipil, Universitas Tarumanagara, Jl. Letjen S. Parman No.1 Jakarta \\ Vittorio@ft.untar.ac.id
}

Masuk: 11-01-2021, revisi: 28-01-2021, diterima untuk diterbitkan: 25-05-2021

\begin{abstract}
Flood is a disaster caused by various factors. Floods have caused many losses, ranging from disruption to daily activities to the loss of a person's life. Kelapa Gading is an area that is often hit by floods. This indicates that there are many factors that can cause flooding in Kelapa Gading. This study aims to find the factors that cause Kelapa Gading to be frequently flooded and solutions to reduce flooding in the area. There are several factors that needs to be examined, rainfall, drainage capacity, and drainage conditions. Drainage capacity will be calculated using the Manning method to determine the discharge from the existing drainage channel. Then it will be compared with the discharge caused by rainfall. From the results of the analysis, it is known that 12 of the 32 channels reviewed are not able to accommodate runoff discharge. After the analysis, it can be concluded that the factors that cause flooding are from the capacity of the drainage channels and external factors such as the presence of sediment at the bottom of the channel or the channel is obstructed by road construction. The solutions to this problem, deepening drainage channels or making infiltration wells in flood-prone areas.
\end{abstract}

Keywords: flood, drainage, rainfall

\begin{abstract}
ABSTRAK
Banjir adalah sebuah bencana yang disebabkan oleh berbagai faktor-faktor. Banjir telah menyebabkan banyaknya kerugian, mulai dari gangguan untuk melakukan aktivitas sehari-hari sampai dengan hilangnya nyawa seseorang. Kecamatan Kelapa Gading merupakan wilayah yang sering dilanda banjir. Hal tersebut menandakan ada banyak faktor yang bisa menyebabkan terjadi banjir di daerah Kelapa Gading. Penelitian ini bertujuan untuk mencari faktorfaktor yang menyebabkan daerah Kelapa Gading sering dilanda banjir dan solusi untuk mengurangi banjir di daerah Kelapa Gading. Ada berberapa faktor yang perlu diteliti yaitu curah hujan, kapasitas drainase, dan kondisi drainase. Kapasitas drainase akan dihitung menggunakan Manning method untuk menentukan debit dari saluran drainase eksisting. Kemudian akan dibandingkan dengan debit yang diakibatkan oleh curah hujan. Dari hasil analisis yang diperoleh diketahui bahwa 12 dari 32 saluran yang ditinjau tidak mampu menampung debit limpasan. Setelah analisis dapat disimpulkan faktor-faktor yang menyebabkan banjir ada dari kapasitas saluran drainase dan faktor luar seperti adanya sedimen di dasar saluran atau saluran terhambat oleh pembangunan jalan. Solusi untuk menangani hal tersebut ada dua yaitu memperdalam saluran drainase atau membuat sumur resapan pada daerah yang rawan banjir.
\end{abstract}

Kata kunci: banjir, drainase, curah hujan.

\section{PENDAHULUAN}

Kecamatan Kelapa Gading merupakan kecamatan yang terletak di Kotamadya Jakarta Utara, Daerah Khusus Ibukota Jakarta, Indonesia. Kelapa Gading berbatasan dengan Kecamatan Koja di bagian Utara, Kecamatan Cakung dan Cilincing di bagian Timur, Kecamatan Pulo Gadung di bagian Selatan, dan Kecamatan Tanjung Priok di bagian Barat. Secara administratif terdiri 3 kelurahan, 56 RW, 585 RT, dengan jumlah penduduk 104.984 jiwa dan 31.823 KK. Dengan kepadatan penduduk $6.512 \mathrm{jiwa} / \mathrm{km}^{2}$ (Dinas Komunikasi, Informatika dan Statistik Pemprov DKI Jakarta) . 
Di Kecamatan Kelapa Gading sebagian besar daerahnya merupakan pemukiman dan daerah perekonomian. Namun daerah ini rentan terkena genangan air/banjir dengan jangka waktu yang cukup lama sebagai contoh pada tahun 2007 bulan Februari, kemudian banjir yang terjadi pada bulan Februari 2018 dan yang terbaru bulan Januari-Februari tahun ini. Setiap kali terjadi banjir di daerah Kelapa Gading, akan terjadi penurunan dalam sektor perekonomian dikarenakan tertutupnya akses ke kelapa gading yang diakibat oleh banjir. Contohnya pada 8 Februari 2020 akses keempat pusat perbelanjaan tertutup dikarenakan banjir dan keempat pusat perbelanjaan yang terdampak banjir kali ini adalah Mall Artha Gading, Mall Kelapa Gading, Mall of Indonesia, dan Sports Mall Kelapa Gading (Novika).

Banyak hal yang mungkin dapat banjir pada daerah Kelapa Gading salah satunya adalah penurunan dalam pelayanan sistem drainase, sistem jaringan, dan kapasitas drainase yang tidak memadai dan mutu operasi saluran drainase yang masih dibawah standar. Maka dari itu diperlukan penelitian seperti analisis kapasitas saluran drainase sehingga sistem drainase selalu berjalan secara optimal.

Permasalahan pada jurnal ini dirumuskan sebagai berikut:

- $\quad$ Apakah kapasitas saluran drainase eksisting dapat menampung debit air dari curah hujan yang terjadi?

- Apakah penyebab terjadinya genangan air atau banjir di daerah Kelapa Gading?

Tujuan Penelitian dari jurnal ini adalah sebagai berikut:

- Untuk mengetahui penyebab utama terjadi genangan air / banjir yang terjadi di daerah Kelapa Gading.

- Untuk mencari solusi mengatasi genangan air/banjir yang terjadi di daerah Kelapa Gading

\section{Banjir}

Banjir adalah aliran atau genangan air yang menimbulkan kerugian ekonomi atau sampai menyebabkan kematian seseorang dan menerut (Badan Standardisasi Nasional) banjir adalah peristiwa meluapnya air sungai melebihi palung sungai atau genangan air yang terjadi pada daerah yang rendah dan tidak bisa terdrainasikan.

\section{Uji Distribusi dan Fungsi Distribusi}

Terdapat 4 jenis distribusi untuk menghitung curah hujan yaitu Distribusi Normal, Distribusi Log Normal, Distribusi Log Pearson III, dan Distribusi Gumbel (Upono and Kusumawardani).

1. Distribusi Normal

Distribusi Normal bertujuan untuk menganalisis frekuensi curah hujan, analisis statistik berdasarkan distribusi curah hujan tahunan, debit rata-rata tahunan. Sebaran normal atau kurva normal disebut juga sebagai sebaran Gauss. Rumus yang digunakan dalam perhitungan adalah:

$$
\log X_{t}=\bar{X}+K_{t} \cdot S_{x}
$$

dengan $\mathrm{X}_{\mathrm{t}}=$ curah hujan rencana $(\mathrm{mm} / \mathrm{hari}), \overline{\mathrm{X}}=$ curah hujan maksimum rata-rata $(\mathrm{mm} / \mathrm{hari}), \mathrm{S}_{\mathrm{x}}=$ standar deviasi, dan $\mathrm{z}=$ faktor frekuensi.

\section{Distribusi Log Normal}

Distribusi Log Norma merupakan hasil transformasi dari distribusi normal, dengan mengubah varian X menjadi nilai logaritmik varian X. Rumus yang digunakan dalam perhitungan metode ini adalah sebagai berikut:

$$
\log X_{t}=\bar{X}+K_{t} \cdot S_{x}
$$

dengan Log $\mathrm{X}_{\mathrm{t}}=$ Besarnya curah hujan yang mungkin terjadi pada periode ulang $\mathrm{T}$ tahun (mm/hari), $\overline{\mathrm{X}}=\mathrm{Curah}$ Hujan Maksimum rata-rata (mm/hari), $\mathrm{K}_{\mathrm{t}}=$ standar variabel , dan $\mathrm{S}_{\mathrm{x}}=$ standar deviasi.

\section{Distribusi Log Pearson III}

Distribusi ini merupakan hasil transformasi dari distribusi Pearson III dengan merubah varian x menjadi nilai log varian $\mathrm{x}$. Hujan rencana kala ulang $\mathrm{T}$ (tahun) dihitung dengan menggunakan anti log.

- Menghitung harga rata-rata dengan rumus:

$$
\log \overline{\mathrm{X}}=\frac{\sum_{\mathrm{i}=1}^{\mathrm{n}} \log \left(\mathrm{X}_{\mathrm{i}}\right)}{\mathrm{n}}
$$

dengan $\log \bar{X}=$ harga rata-rata logaritma, $X_{i}=$ Nilai curah hujan, dan $\mathrm{n}=$ jumlah data.

- Menghitung logaritma hujan rencana dengan periode ulang $\mathrm{T}$ tahun dengan rumus : 
Dengan $\mathrm{S}=$ Standar deviasi

$$
\mathrm{S}=\frac{\sum_{\mathrm{i}=1}^{\mathrm{n}}\left\{\log \left(\mathrm{X}_{\mathrm{i}}\right)-\log (\overline{\mathrm{X}})\right\}^{2}}{\mathrm{n}-1}
$$

- Menghitung koefisien skewness (Cs) dengan rumus :

Dengan Cs = Koefisien Skewness

$$
\mathrm{C}_{\mathrm{s}}=\frac{\sum_{\mathrm{i}=1}^{\mathrm{n}}\left\{\log \left(\mathrm{X}_{\mathrm{i}}\right)-\log (\overline{\mathrm{X}})\right\}^{2}}{(\mathrm{n}-1)(\mathrm{n}-2) \mathrm{S}^{3}}
$$

- Menghitung logaritma hujan rencana dengan periode ulang $\mathrm{T}$ tahun dengan rumus :

$$
\begin{aligned}
\log Y & =\log \bar{X}+k \cdot S \\
X_{t} & =10^{(\log Y)}
\end{aligned}
$$

dengan $\mathrm{X}_{\mathrm{t}}=$ Curah hujan rencana periode ulang $\mathrm{T}$ tahun, $\mathrm{k}=$ Harga yang diperoleh bedasarkan nilai Cs dan $\mathrm{S}=$ standar deviasi

\section{Distribusi Gumbel}

Distribusi Gumbel digunakan untuk analisis data maksimum, sebagai contoh untuk analisis frekuensi banjir, dengan rumus sebagai berikut:

$$
X_{t}=\bar{x}+\frac{\left(Y_{t}-Y_{n}\right)}{S_{n}} \times S_{X}
$$

dengan $\mathrm{Yt}=$ Reiduced variable, parameter Gumbel untuk periode $\mathrm{T}$ tahun, $\mathrm{Yn}=$ Reduced mean, merupakan fungsi dari banyaknya data dan $\mathrm{Sn}=$ Reduced standar deviasi, merupakan fungsi dari banyak data.

Jenis sebaran fungsi distribusi yang sering digunakan pada analisis frekuensi untuk hujan ekstrim di Indonesia adalah Uji Chi-Square dan Uji Kolmogorov-Smirnov. (SNI 2415:2016)

\section{Uji Chi-Square}

Metode ini menganggap pengamatan pembentukan variabel acak yang dilakukan secara statistik dengan mengikuti kurva distribusi Chi-Square dengan derajat kebebasan k-p-1, dengan p merupakan jumlah parameter yang diestimasi dari data. Uji statistik ini berdasarkan pada bobot jumlah kuadrat perbedaan antara pengamatan dan teoritisnya yang dibagi dalam kelompok kelas. Bandingkan $X^{2}$ hitungan dengan $X^{2}$ kritis, bila hitungan $X^{2}<X^{2}$ kritis, berarti metode distribusi yang diperiksa dapat diterima.

\section{Uji Kolmogorov-Smirnov}

Uji kecocokan ini merupakan uji kecocokan "nonparametric" karena tidak mengikuti distribusi tertentu. Uji ini menghitung besarnya jarak maksimum secara vertikal antara pengamatan dan teoritis dari distribusi sampelnya. Distribusi dikatakan cocok jika nilai Dn $<$ D kritisnya pada derajat kepercayaan yang diinginkan.

\section{Debit Metode Rasional dan Metode Manning}

Debit Metode Rasional ini dapat menggambarkan hubungan antara debit limpasan dengan besar curah hujan secara praktis dan dua komponen utama dalam rumus ialah waktu konsentrasi (tc) dan intensitas curah hujan (I), persamaan yang digunakan (Badan Standardisasi Nasional):

$$
\mathrm{Qp}=0,00278 \text { C.I. A }
$$

dengan $\mathrm{Qp}=$ Debit Puncak $\left(\mathrm{m}^{3} / \mathrm{s}\right), \mathrm{C}=$ Koefisien Limpasan, I= Intensitas hujan selama waktu konsentrasi (mm/jam), A= Luas Daerah Aliran (Ha).

Untuk keperluan praktis dalam mencari nilai kecepatan aliran, maka aliran dalam saluran dapat dianggap seragam dalam keadaan normal, yaitu apabila tidak terjadi banjir atau aliran berubah yang jelas akibat ketidakaturan saluran. Maka dapat digunakan metode Manning dalam kondisi tersebut, persamaan metode Manning sebagai berikut menurut (Kementerian Pekerjaan Umum):

$$
\begin{aligned}
& V=\frac{1}{n} \cdot R^{\frac{2}{3}} \cdot I^{\frac{1}{2}} \\
& Q=A \cdot \frac{1}{n} \cdot R^{\frac{2}{3}} \cdot I^{\frac{1}{2}}
\end{aligned}
$$

dengan $\mathrm{A}=$ Luas basah saluran $\left(\mathrm{m}^{2}\right), \mathrm{n}=$ Koefisien Manning, $\mathrm{R}=$ Jari-jari hidrolis, $\mathrm{I}=$ Kemiringan dasar saluran, $\mathrm{Q}=$ Debit Saluran $\left(\mathrm{m}^{3} / \mathrm{s}\right)$. 


\section{HEC-RAS}

Hydrologic Engineering Center's (HEC) dan River Analysis System (RAS) adalah program yang digunakan untuk memodelkan satu dimensi dan dua dimensi perhitungan hidrolika aliran tidak tetap. Fitur HEC-RAS terdiri dari empat bagian perhitungan hidrolika yaitu perhitungan profil muka air aliran permanen, simulasi aliran tidak permanen, perhitungan perpindahan sedimen (mobile bed dan moveable boundary), dan yang terakhir analisis kualitas air.

\section{METODE PENELITIAN}

\section{Pengumpulan data}

Dalam penelitian ini data yang diperlukan sebagai berikut:

- Peta Sebaran Titik Banjir di Kecamatan Kelapa Gading dari Suku Dinas Sumber Daya Air Kota Jakarta Utara.

- Data Curah Hujan Harian Maksimum stasiun Geofisika Tanjung Priok selama 10 tahun dari Badan Meteorologi Klimatologi dan Geofisika.

- Peta Jaringan Drainase di Kecamatan Kelapa Gading dari Suku Dinas Sumber Daya Air Kota Jakarta Utara.

- Spesifikasi saluran eksisting di Kecamatan Kelapa Gading dari Suku Dinas Sumber Daya Air Kota Jakarta Utara.

- $\quad$ Peta Topografi Kecamatan Kelapa Gading dari Dinas Cipta Karya, Tata Ruang dan Pertanahan DKI Jakarta.

\section{Pengolahan data}

- Mengambil dan mengolah data curah hujan maksimum harian setiap tahun selama 10 tahun

- Melakukan pengujian kecocokan fungsi distribusi dengan menggunakan metode Chi-Square dan KolmogorovSmirnov.

- Menghitung frekuensi curah hujan dengan distribusi yang sudah diuji dengan pengujian kecocokan fungsi distribusi.

- Melakukan Perhitungan kapasitas saluran drainase eksisting.

- Menghitung debit limpasan dengan metode Rasional.

- Menganalisis debit saluran eksisting mampu menampung debit limpasan dengan metode Rasional atau tidak.

- Menganalisis saluran drainase rencana.

- Melakukan pemodelan terhadap saluran rencana dengan aplikasi HEC-RAS.

\section{HASIL DAN PEMBAHASAN}

\section{Perhitungan curah hujan rencana}

Data yang digunakan untuk mencari curah hujan rencana adalah curah hujan harian maksimum. Data tersebut diperoleh dari stasiun terdekat yaitu stasiun Tanjung Priok. Data Curah hujan yang digunakan yaitu periode tahun 2010 sampai dengan periode tahun 2019 terdapat pada Tabel 1:

Tabel 1. Tabel Curah Hujan Harian Maksimum (Badan Meteorologi, Klimatologi, dan Geofisika)

\begin{tabular}{ccc}
\hline No & Tahun & Curah Hujan $(\mathrm{mm})$ \\
\hline 1 & 2010 & 88.3 \\
2 & 2011 & 66.4 \\
3 & 2012 & 75.1 \\
4 & 2013 & 117.8 \\
5 & 2014 & 284 \\
6 & 2015 & 247 \\
7 & 2016 & 112.7 \\
8 & 2017 & 148.6 \\
9 & 2018 & 129.6 \\
10 & 2019 & 130.3 \\
\hline Total & & 1399.8 \\
\hline Rata2 & & 139.98 \\
\hline
\end{tabular}

Pengujian distribusi dilakukan terhadap metode frekuensi curah hujan dengan Metode Normal, Log Normal, Gumbel dan Log Pearson III. Bedasarkan pengujian distribusi, disimpulkan bahwa data curah hujan yang dapat digunakan 
untuk perhitungan adalah metode Log Pearson III karena memiliki persyaratan yang memenuhi berikut ditampilkan dalam Tabel 2 dan Tabel 3:

Tabel 2. Hasil Uji Distribusi

\begin{tabular}{cccc}
\hline Distribusi & Persyaratan & Hasil Perhitumgan & Keterangan \\
\hline Normal & $\mathrm{Cs} \approx 0$ & 1.2812048 & Tidak Memenuhi \\
& $\mathrm{Ck} \approx 3$ & 4.681312447 & Tidak Memenuhi \\
Log Normal & $\mathrm{Cs} \approx 3 \mathrm{Cv}$ & $-0.1559 \neq 0.1494$ & Tidak Memenuhi \\
Gumbel & $\mathrm{Cs} \approx 1.1396$ & 1.2812048 & Memenuhi \\
& $\mathrm{Ck} \leq 5.4002$ & 4.681312447 & 0.52638 \\
Log Person III & $\mathrm{Cs} \neq 0$ & &
\end{tabular}

Tabel 3. Hasil Rekapitulasi Uji Chi-Square dan Kolmogorov-Smirnov

\begin{tabular}{|c|c|c|c|c|c|c|c|}
\hline \multirow{2}{*}{ No } & \multirow{2}{*}{ Distribusi } & \multicolumn{2}{|c|}{ Chi-Square } & \multirow{2}{*}{ Kesimpulan } & \multicolumn{2}{|c|}{ Kolmogorov-Smirnov } & \multirow{2}{*}{ Kesimpulan } \\
\hline & & $\mathrm{X}^{2}$ & $\mathrm{X}^{2} \mathrm{Cr}$ & & Do & Dmax & \\
\hline 1 & Normal & 5.991 & 13 & Tidak Diterima & 0.41 & 0.1881 & Diterima \\
\hline 2 & Log Normal & 5.991 & 3 & Diterima & 0.41 & 0.1099 & Diterima \\
\hline 3 & Log Pearson III & 5.991 & 3 & Diterima & 0.41 & 0.1094 & Diterima \\
\hline 4 & Gumbel & 5.991 & 7 & Diterima & 0.41 & 0.4562 & Tidak Diterima \\
\hline
\end{tabular}

Tabel 4. Perhitungan Curah Hujan Rencana dengan Metode Log Pearson III

\begin{tabular}{cccc}
\hline Tahun & $\mathrm{k}$ & $\log \mathrm{Rr}$ & $\mathrm{Rr}(\mathrm{mm})$ \\
\hline 2 & -0.0089 & 2.099436473 & 125.7293 \\
5 & 0.8388 & 2.271421617 & 186.8192 \\
10 & 1.2873 & 2.36241529 & 230.3644 \\
20 & 1.7689 & 2.460124438 & 288.4858 \\
\hline
\end{tabular}

\section{Analisis debit Metode Rasional dan Metode Manning}

Untuk melakukan perhitungan debit metode rasional dibutuhkan data intenstitas hujan, peta jaringan saluran terdapat pada Gambar 1 :

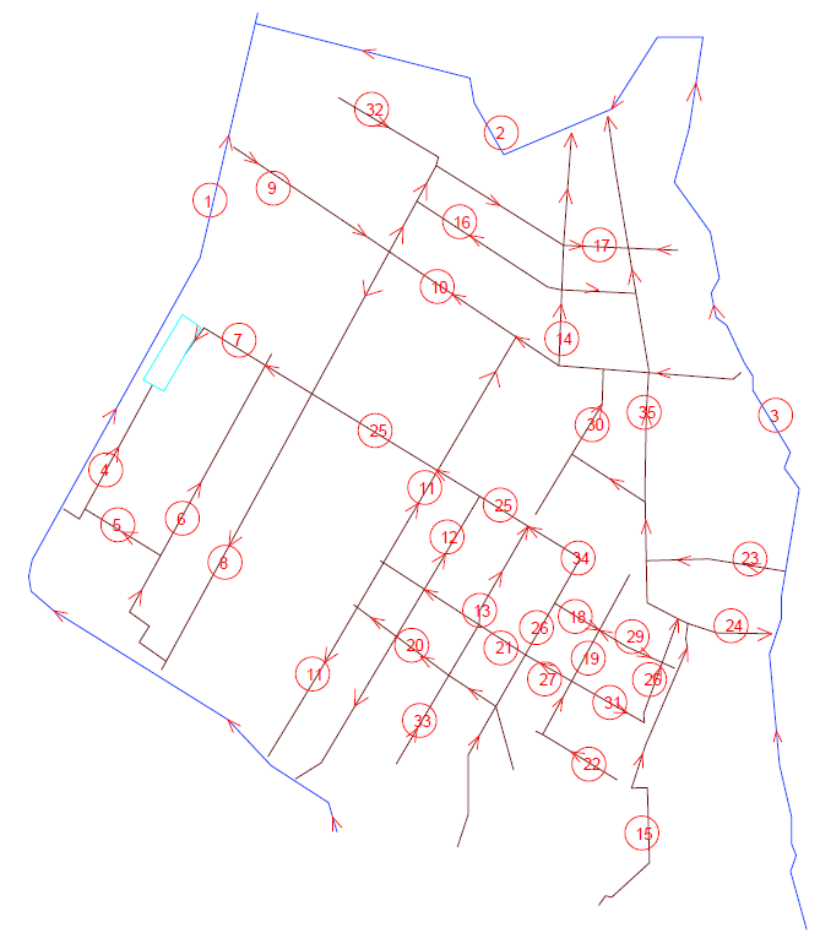

Gambar 1. Peta Jaringan Saluran Drainase Kecamatan Kelapa Gading (Dinas Sumber Daya Air ) 
Perhitungan debit limpasan dengan metode rasional digunakan periode ulang untuk daerah tangkapan air kurang dari $10 \mathrm{Ha}$ di kota metropolitan adalah 2 tahun dan untuk daerah tangkapan air 10-100 Ha di kota metropolitan adalah 2-5 tahun (Kementerian Pekerjaan Umum). Tabel hasil perhitungan metode rasional disajikan pada Tabel 5:

Tabel 5. Perhitungan Debit Rancangan Metode Rasional

\begin{tabular}{|c|c|c|c|c|c|c|c|}
\hline $\begin{array}{c}\text { No } \\
\text { Saluran }\end{array}$ & Posisi & $\begin{array}{l}\text { Intensitas } \\
(\mathrm{mm} / \mathrm{jam})\end{array}$ & $\mathrm{C}$ & $\mathrm{A}(\mathrm{Ha})$ & $\begin{array}{c}\text { A } \\
\text { Kumulatif } \\
(\mathrm{Ha})\end{array}$ & Debit $\left(\mathrm{m}^{3} / \mathrm{s}\right)$ & $\begin{array}{l}\text { Debit } \\
\text { Total } \\
\left(\mathrm{m}^{3} / \mathrm{s}\right)\end{array}$ \\
\hline \multirow{2}{*}{4} & Kiri & 104.6252 & 0.7 & 5.7038 & 5.7038 & \multirow{2}{*}{4.103286935} & \multirow{2}{*}{7.226216} \\
\hline & Kanan & 104.6252 & 0.7 & 14.4498 & 14.4498 & & \\
\hline \multirow{2}{*}{5} & Kiri & 104.6252 & 0.7 & 9.4277 & 9.4277 & \multirow{2}{*}{3.122929236} & \multirow{2}{*}{3.122929} \\
\hline & Kanan & 104.6252 & 0.7 & 5.9108 & 5.9108 & & \\
\hline \multirow{2}{*}{6} & Kiri & 104.6252 & 0.7 & 22.7965 & 22.7965 & \multirow{2}{*}{8.67923288} & \multirow{2}{*}{8.6792329} \\
\hline & Kanan & 104.6252 & 0.7 & 19.8322 & 19.8322 & & \\
\hline \multirow{2}{*}{7} & Kiri & 104.6252 & 0.7 & 9.2806 & 9.2806 & \multirow{2}{*}{7.372116429} & \multirow{2}{*}{29.84072} \\
\hline & Kanan & 104.6252 & 0.7 & 26.9281 & 26.9281 & & \\
\hline \multirow{2}{*}{8} & Kiri & 75.6166 & 0.7 & 36.6561 & 36.6561 & \multirow{2}{*}{16.5254425} & \multirow{2}{*}{21.638292} \\
\hline & Kanan & 75.6166 & 0.7 & 75.6473 & 75.6473 & & \\
\hline \multirow{2}{*}{9} & Kiri & 104.2063 & 0.7 & 18.2783 & 18.2783 & \multirow{2}{*}{7.41714729} & \multirow{2}{*}{7.4171473} \\
\hline & Kanan & 104.2063 & 0.7 & 18.2980 & 18.2980 & & \\
\hline \multirow{2}{*}{10} & Kiri & 104.2063 & 0.7 & 31.7774 & 31.7774 & \multirow{2}{*}{11.73570056} & \multirow{2}{*}{11.735701} \\
\hline & Kanan & 104.2063 & 0.7 & 26.0951 & 26.0951 & & \\
\hline \multirow{2}{*}{11} & Kiri & 75.6166 & 0.7 & 67.2785 & 67.2785 & \multirow{2}{*}{14.14988274} & \multirow{2}{*}{16.827026} \\
\hline & Kanan & 75.6166 & 0.7 & 28.8811 & 28.8811 & & \\
\hline \multirow{2}{*}{12} & Kiri & 75.6166 & 0.7 & 17.5659 & 17.5659 & \multirow{2}{*}{5.702223396} & \multirow{2}{*}{5.7022234} \\
\hline & Kanan & 75.6166 & 0.7 & 21.1852 & 21.1852 & & \\
\hline 13 & Kiri & 75.6166 & 0.7 & 5.6284 & 5.6284 & 1717093058 & 17170931 \\
\hline & Kanan & 75.6166 & 0.7 & 6.0406 & 6.0406 & & \\
\hline 14 & Kiri & 104.2063 & 0.7 & 14.3433 & 14.3433 & 4.688855714 & 15.611508 \\
\hline & Kanan & 104.2063 & 0.7 & 8.77895 & 8.77895 & & \\
\hline 15 & Kiri & 123.3418 & 0.7 & 9.9234 & 9.9234 & 46757481 & 46757481 \\
\hline 10 & Kanan & 123.3418 & 0.7 & 9.557 & 9.5570 & משר & 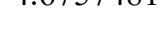 \\
\hline 16 & Kiri & 104.2063 & 0.7 & 14.3713 & 14.3713 & 5112849658 & 51128497 \\
\hline & Kanan & 104.2063 & 0.7 & 10.8418 & 10.8418 & 0.112049000 & 5.1120491 \\
\hline 17 & Kiri & 104.2063 & 0.7 & 21.3412 & 29.9486 & 10.92265261 & 10.922653 \\
\hline & Kanan & 104.2063 & 0.7 & 20.0795 & 23.9145 & 10.92200201 & 10.922035 \\
\hline 18 & Kiri & 123.3418 & 0.7 & 1.8027 & 1.8027 & 0.821791459 & 0.8217915 \\
\hline & Kanan & 123.3418 & 0.7 & 1.6211 & 1.6211 & & \\
\hline 19 & Kiri & 75.6166 & 0.7 & 9.0964 & 9.0964 & 3.075449193 & 5.7641177 \\
\hline & Kanan & 75.6166 & 0.7 & 11.8037 & 11.8037 & & \\
\hline 20 & Kiri & 75.6166 & 0.7 & 5.0781 & 5.0781 & 1.227260222 & 1.2272602 \\
\hline & Kanan & 75.6166 & 0.7 & 3.2621 & 3.2621 & $1.22 / 200222$ & 1.2212002 \\
\hline 21 & Kiri & 75.6166 & 0.7 & 4.4594 & 4.4594 & 1449883419 & 14408824 \\
\hline 21 & Kanan & 75.6166 & 0.7 & 5.3937 & 5.3937 & 1.449005419 & 1.4490054 \\
\hline
\end{tabular}


Tabel 5. Perhitungan Debit Rancangan Metode Rasional (Lanjutan)

\begin{tabular}{|c|c|c|c|c|c|c|c|}
\hline $\begin{array}{c}\text { No } \\
\text { Saluran }\end{array}$ & Posisi & $\begin{array}{l}\text { Intensitas } \\
(\mathrm{mm} / \mathrm{jam})\end{array}$ & $\mathrm{C}$ & A (Ha) & $\begin{array}{c}\text { A } \\
\text { Kumulatif } \\
(\mathrm{Ha})\end{array}$ & Debit $\left(\mathrm{m}^{3} / \mathrm{s}\right)$ & $\begin{array}{l}\text { Debit } \\
\text { Total } \\
\left(\mathrm{m}^{3} / \mathrm{s}\right) \\
\end{array}$ \\
\hline \multirow{2}{*}{22} & Kiri & 75.6166 & 0.7 & 7.1823 & 7.1823 & \multirow{2}{*}{1.866877018} & \multirow{2}{*}{1.866877} \\
\hline & Kanan & 75.6166 & 0.7 & 5.5046 & 5.5046 & & \\
\hline \multirow{2}{*}{23} & Kiri & 104.2063 & 0.7 & 8.6231 & 8.6231 & \multirow{2}{*}{5.734650663} & \multirow{2}{*}{5.7346507} \\
\hline & Kanan & 104.2063 & 0.7 & 19.6563 & 19.6563 & & \\
\hline \multirow{2}{*}{24} & Kiri & 123.3418 & 0.7 & 8.202 & 8.2020 & \multirow{2}{*}{5.052872564} & \multirow{2}{*}{15.229561} \\
\hline & Kanan & 123.3418 & 0.7 & 12.8496 & 12.8496 & & \\
\hline \multirow{2}{*}{25} & Kiri & 75.6166 & 0.7 & 19.642 & 19.642 & \multirow{2}{*}{5.900110683} & \multirow{2}{*}{11.926358} \\
\hline & Kanan & 75.6166 & 0.7 & 20.4539 & 20.4539 & & \\
\hline \multirow{2}{*}{26} & Kiri & 123.3418 & 0.7 & 6.1236 & 6.1236 & \multirow{2}{*}{2.004553821} & \multirow{2}{*}{4.4420375} \\
\hline & Kanan & 123.3418 & 0.7 & 2.2279 & 2.2279 & & \\
\hline \multirow{2}{*}{27} & Kiri & 75.6166 & 0.7 & 1.4233 & 1.4233 & \multirow{2}{*}{0.452662753} & \multirow{2}{*}{0.4526628} \\
\hline & Kanan & 75.6166 & 0.7 & 1.6529 & 1.6529 & & \\
\hline \multirow{2}{*}{28} & Kiri & 75.6166 & 0.7 & 18.7411 & 18.7411 & \multirow{2}{*}{5.314262487} & \multirow{2}{*}{5.3142625} \\
\hline & Kanan & 75.6166 & 0.7 & 17.3735 & 17.3735 & & \\
\hline \multirow{2}{*}{29} & Kiri & 123.3418 & 0.7 & 2.4065 & 2.4065 & \multirow{2}{*}{1.125516827} & \multirow{2}{*}{1.1255168} \\
\hline & Kanan & 123.3418 & 0.7 & 2.2827 & 2.2827 & & \\
\hline \multirow{2}{*}{30} & Kiri & 103.6902 & 0.7 & 15.6957 & 15.6957 & \multirow{2}{*}{5.153368537} & \multirow{2}{*}{5.1533685} \\
\hline & Kanan & 103.6902 & 0.7 & 9.8437 & 9.8437 & & \\
\hline \multirow{2}{*}{31} & Kiri & 123.3418 & 0.7 & 2.6731 & 2.6731 & \multirow{2}{*}{1.311966855} & \multirow{2}{*}{1.3119669} \\
\hline & Kanan & 123.3418 & 0.7 & 2.7929 & 2.7929 & & \\
\hline \multirow{2}{*}{32} & Kiri & 104.2063 & 0.7 & 13.2924 & 13.2924 & 3794277871 & 37942779 \\
\hline & Kanan & 104.2063 & 0.7 & 5.4184 & 5.4184 & 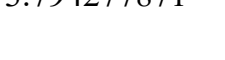 & 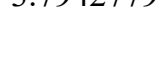 \\
\hline 33 & Kiri & 75.6166 & 0.7 & 9.9328 & 9.9328 & 2.905876504 & 29058765 \\
\hline & Kanan & 75.6166 & 0.7 & 9.81492 & 9.8149 & & 2.0000100 \\
\hline 34 & Kiri & 75.6166 & 0.7 & 2.7577 & 2.7577 & 0711985154 & 60262476 \\
\hline 34 & Kanan & 75.6166 & 0.7 & 2.0808 & 2.0808 & 0.711985154 & $0.02024 / 0$ \\
\hline 35 & Kiri & 104.2063 & 0.7 & 27.3881 & 27.3881 & 1056808226 & 16302733 \\
\hline 32 & Kanan & 104.2063 & 0.7 & 24.7265 & 24.7265 & 10.50000220 & 10.502155 \\
\hline
\end{tabular}

Perhitungan kapasitas debit saluran eksisting menggunakan koefisien Manning 0,025 untuk pasangan batu dan kemiringan diambil dari peta topografi. Apabila beda ketinggian terlalu kecil sehingga pada perhitungan diasumsikan $\mathrm{I}=0,0002$. Berikut perhitungan kapasitas saluran eksisiting dengan rumus Manning disajikan pada Tabel 6: 
Tabel 6. Hasil Perhitungan Debit Saluran Eksisting

\begin{tabular}{|c|c|c|c|c|c|c|c|}
\hline $\begin{array}{l}\text { No } \\
\text { Saluran }\end{array}$ & Nama Saluran & $\begin{array}{l}\text { Panjang } \\
(\mathrm{m})\end{array}$ & $\begin{array}{l}\text { Lebar } \\
\text { Saluran } \\
(\mathrm{m})\end{array}$ & $\begin{array}{l}\text { Tinggi } \\
\text { Saluran } \\
(\mathrm{m})\end{array}$ & Kemiringan & $\begin{array}{c}\mathrm{V} \\
(\mathrm{m} / \mathrm{s})\end{array}$ & $\begin{array}{l}\text { Debit } \\
\left(\mathrm{m}^{3} / \mathrm{s}\right)\end{array}$ \\
\hline 4 & PHB TABAH RAYA & 995 & 3,8 & 3 & 0,0003 & 0,7525 & 8,0064 \\
\hline 5 & PHB TABAH 1 & 505 & 3,1 & 1,7 & 0,0005 & 0,7464 & 3,4707 \\
\hline 6 & PHB PULAU BANGKA & 2121 & 4 & 1,5 & 0,0005 & 0,7409 & 3,8527 \\
\hline 7 & PHB BALAI SAMUDRA & 611 & 15 & 6 & 0,0002 & 1,1050 & 91,1620 \\
\hline 8 & PHB BUKIT GADING & 3546 & 15 & 6 & 0,0002 & 1,1235 & 92,6916 \\
\hline 9 & PHB ARTHA GADING & 1127 & 4 & 3 & 0,0005 & 0,9863 & 10,8489 \\
\hline 10 & $\begin{array}{l}\text { PHB KELAPA NIAS } \\
\text { RAYA }\end{array}$ & 2415 & 7 & 1,6 & 0,0004 & 0,7999 & 7,5592 \\
\hline 11 & PHB PELEPAH & 2752 & 4 & 5 & 0,0002 & 0,7089 & 13,3281 \\
\hline 12 & $\begin{array}{l}\text { PHB BOULEVARD } \\
\text { SELATAN }\end{array}$ & 1725 & 6 & 2,7 & 0,0002 & 0,6905 & 10,1505 \\
\hline 13 & $\begin{array}{l}\text { PHB GADING ELOK } \\
\text { UTARA }\end{array}$ & 602 & 2,6 & 1,8 & 0,0002 & 0,4533 & 1,8856 \\
\hline 14 & $\begin{array}{l}\text { PHB BOULEVARD } \\
\text { UTARA }\end{array}$ & 1319 & 6 & 3 & 0,0004 & 0,9844 & 15,9470 \\
\hline 15 & PHB KEPU & 2021 & 4 & 1,5 & 0,0004 & 0,6824 & 3,5487 \\
\hline 16 & PHB JANUR ELOK & 1450 & 4 & 5 & 0,0002 & 0,7089 & 13,3281 \\
\hline 17 & PHB KELAPA HIBRIDA & 1632 & 6 & 1,5 & 0,0006 & 0,9109 & 6,8316 \\
\hline 18 & PHB KAPARINYO & 255 & 3,4 & $1,, 1$ & 0,0004 & 0,5618 & 1,7191 \\
\hline 19 & PHB TARIAN RAYA & 945 & 8,8 & 2 & 0,0002 & 0,6571 & 10,1198 \\
\hline 20 & $\begin{array}{l}\text { PHB KELAPA KOPYOR } \\
\text { RAYA }\end{array}$ & 695 & 6 & 4 & 0,0003 & 0,9342 & 19,6179 \\
\hline 21 & PHB KELAPA CENGKIR & 684 & 2,5 & 1,5 & 0,0004 & 0,5924 & 1,9254 \\
\hline 22 & PHB ACORDION & 300 & 2,3 & 1,2 & 0,0002 & 0,3727 & 0,8573 \\
\hline 23 & PHB GADING ARCADIA & 819 & 6,8 & 3 & 0,0003 & 0,8971 & $15,860 \mathrm{c}$ \\
\hline 24 & PHB TEMBUS GADING & 813 & 12 & 4 & 0,0003 & 1,1903 & 49,9917 \\
\hline 25 & PHB KELAPA PUAN & 1512 & 5,4 & 3 & 0,0004 & 0,9649 & 13,5466 \\
\hline 26 & $\begin{array}{l}\text { PHB PEGANGSAAN } \\
\text { INDAH BARAT }\end{array}$ & 532 & 4 & 2 & 0,0002 & 0,5457 & 3,9287 \\
\hline 27 & PHB GIRING -GIRING & 296 & 3,4 & 1,5 & 0,0004 & 0,6525 & 2,8842 \\
\hline 28 & PHB BIRU LAUT TIMUR & 960 & 4 & 2,7 & 0,0002 & 0,6032 & 5,9114 \\
\hline 29 & $\begin{array}{l}\text { PHB } \\
\text { DEPOSITO/TABANAS }\end{array}$ & 376 & 3,3 & 1,7 & 0,0004 & 0,6812 & 3,3719 \\
\hline 30 & PHB GADING INDAH & 873 & 2,6 & 1,8 & 0,0004 & 0,6410 & 2,6666 \\
\hline 31 & PHB BONGO-BANYO & 433 & 3,5 & 1,4 & 0,0003 & 0,5524 & 2,3199 \\
\hline 32 & PHB GADING KIRANA & 790 & 6 & 2,2 & 0,0004 & 0,8849 & 10,0874 \\
\hline 33 & $\begin{array}{l}\text { PHB GADING PUTIH } \\
\text { RAYA }\end{array}$ & 956 & 2,6 & 1,8 & 0,0005 & 0,7167 & 2,9814 \\
\hline 34 & PHB JINGGA RAYA & 341 & 5,4 & 3,2 & 0,0003 & 0,8663 & 13,5663 \\
\hline 35 & PHB KELAPA LILIN & 2842 & 6 & 3 & 0,0004 & 0,9484 & 15,3640 \\
\hline
\end{tabular}


Setelah didapat perhitungan teoritas dilakukan pengecekan dengan menggunakan program HEC-RAS, hasil yang diperoleh HEC-RAS mirip dengan perhitungan teoritis. Contoh program HEC-RAS seperti pada Gambar 2:

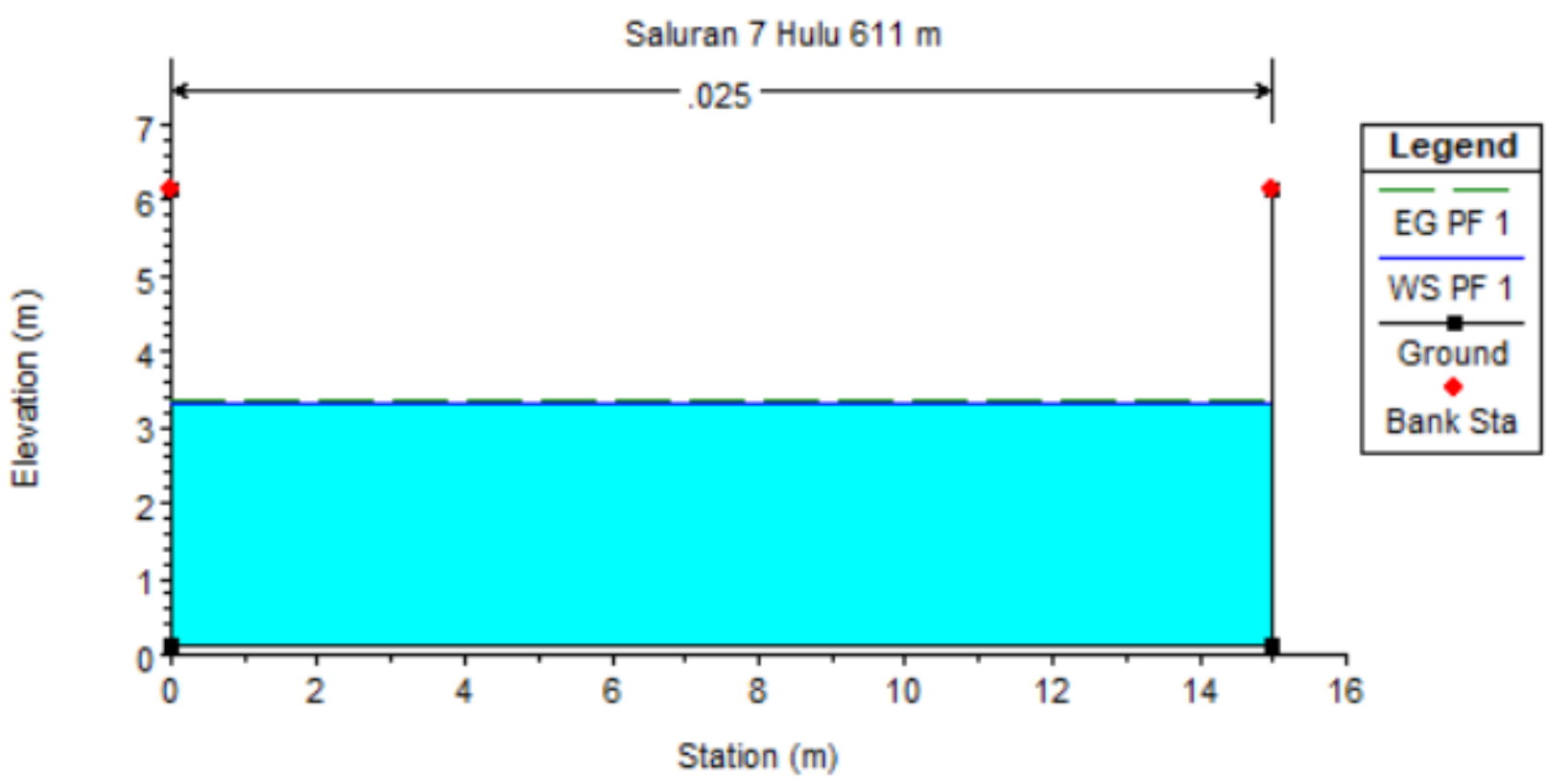

Gambar 2. Pemodelan Saluran 7 Bagian Hulu

Dari hasil rekapitulasi perbandingan debit saluran, dapat disimpulkan dari 32 saluran ada 12 saluran yang tidak memenuhi secara perhitungan teoritis. Tetapi pada kenyataan terjadi perbedaan antara perhitungan teoritis dengan realitas, sebagai contoh menurut perhitungan teoritis saluran 7 (PHB Balai Samudra) memenuhi sedangkan pada kenyataannya terjadi banjir di lokasi tersebut. Hal ini disebabkan oleh adanya faktor lain yang mengakibatkan banjir di lokasi tersebut. Faktor-faktor lain adalah sebagai berikut ini:

1. Saluran yang terdampak akibat pembangunan jalan tol. Contohnya adalah saluran Boulevard Barat yang kondisi salurannya tidak mengalir ke saluran berikutnya sehingga air melimpas ke jalan.

2. Mayoritas saluran memiliki sedimen di bagian dasar saluran. Contohnya adalah saluran Kelapa Kopyor dan Pengangsaan Dua yang terdapat sedimen pada dasar saluran maka perlu dilakukan pengurasan atau pengurugan.

3. Banyaknya sampah dengan ukuran yang cukup besar di dalam saluran sehingga menghambat aliran air. Contohnya seperti pada saluran Bukit Gading.

\section{Solusi}

Solusi yang diusulkan ada dua macam yaitu pertama melakukan perbesaran penampang saluran dan pembuatan sumur resapan, kemudian keduan macam solusi ini memiliki kelebihan dan kekurangan masing-masing tergantung kondisi lingkungan yang diterapkan.

1.Saluran Drainase Rencana

Karena adanya saluran yang sudah tidak mampu menampung debit dari curah hujan yang terjadi, maka salah satu cara untuk mengatasinya adalah dengan mendesain ulang saluran. Untuk perhitungan dibawah ini semua parameter yang tidak ditampilkan berarti sama seperti desain awal. Berikut ini adalah hasil analisisnya disajikan pada Tabel 7: 
Tabel 7. Analisis Debit Saluran Rencana

\begin{tabular}{|c|c|c|c|c|c|}
\hline $\begin{array}{l}\text { No } \\
\text { Saluran }\end{array}$ & Nama Saluran & $\begin{array}{l}\text { Lebar } \\
\text { Saluran } \\
\text { (m) }\end{array}$ & $\begin{array}{l}\text { Tinggi } \\
\text { Saluran } \\
(\mathrm{m})\end{array}$ & $\begin{array}{c}\mathrm{V} \\
(\mathrm{m} / \mathrm{s})\end{array}$ & $\begin{array}{l}\text { Debit } \\
\left(\mathrm{m}^{3} / \mathrm{s}\right)\end{array}$ \\
\hline 6 & PHB PULAU BANGKA & - & 3 & 0,9577 & 10,5349 \\
\hline 10 & $\begin{array}{l}\text { PHB KELAPA NIAS } \\
\text { RAYA }\end{array}$ & - & 3 & 1,0467 & 18,3180 \\
\hline 11 & PHB PELEPAH & 6,5 & 6 & 0,9108 & 32,5594 \\
\hline 13 & $\begin{array}{c}\text { PHB GADING ELOK } \\
\text { UTARA }\end{array}$ & - & 2.5 & 0,4998 & 2,9890 \\
\hline 14 & $\begin{array}{l}\text { PHB BOULEVARD } \\
\text { UTARA }\end{array}$ & - & 4 & 1,0722 & 22,5161 \\
\hline 17 & PHB KELAPA HIBRIDA & - & 3 & 1,2176 & 18,2638 \\
\hline 22 & PHB ACORDION & - & 2 & 1,8236 & 7,5497 \\
\hline 25 & PHB KELAPA PUAN & 6 & 4,8 & 1,3448 & 34,6971 \\
\hline 28 & $\begin{array}{l}\text { PHB BIRU LAUT } \\
\text { TIMUR }\end{array}$ & - & 3 & 1.1477 & 12.6247 \\
\hline 30 & PHB GADING INDAH & 3 & 3 & 0.7842 & 6.4699 \\
\hline 33 & $\begin{array}{l}\text { PHB GADING PUTIH } \\
\text { RAYA }\end{array}$ & 3 & 3 & 0.5569 & 4.6778 \\
\hline 35 & PHB KELAPA LILIN & - & 3.8 & 1.0142 & 20.0806 \\
\hline
\end{tabular}

\section{Sumur Resapan}

Menurut penelitian yang berjudul "Kajian Efektivitas Sumur Resapan Dalam Mengurangi Resiko Bencana Banjir Di Kota Jakarta" (Nurul Fajar Januriyadi) dengan sumur resapan berkedalaman 3.5 m, bahwa sumur resapan tersebut dapat mengurangi debit banjir sebesar 3-13\%. Untuk analisis kita ambil nilai persentase $8 \%$ untuk skenario 1 dan $13 \%$ skenario 2. Kemudian skenario 1 (8\%) jumlah sumur resapan 400 per km² dan scenario 2 (13\%) jumlah sumur resapan 500 per $\mathrm{km}^{2}$. Kemudian kita lakukan analisis dampak sumur resapan terhadap saluran yang tidak memenuhi kapasitasnya. Hasil Analisis terdapat di Tabel 8:

Tabel 8. Jumlah Saluran yang Tidak Memenuhi Setelah Menggunakan Sumur Resapan

\begin{tabular}{ccc}
\hline \multicolumn{3}{c}{ Jumlah Saluran yang Tidak Memenuhi } \\
\hline Normal & $\begin{array}{c}\text { Ditambah Sumur } \\
\text { Resapan (8\%) }\end{array}$ & $\begin{array}{c}\text { Ditambah Sumur } \\
\text { Resapan (13\%) }\end{array}$ \\
\hline 12 & 12 & 9
\end{tabular}

Karena menerut hasil analisis dari 12/32 saluran yang tidak mampu menampung berkurang menjadi 9/32 saluran apabila sumur resapan dapat mengurangi 13\% dari debit limpasan yang terjadi. Sebagai contoh bila di implementasikan di saluran 13 yang memiliki luas daerah tangkapan sebesar 11,669 Ha maka dibutuhkan 60 buah sumur resapan pada daerah saluran tersebut. Caranya dengan membuat satu sumur resapan pada setiap bangunan yang ada di daerah tersebut. Kemudian saluran yang menggunakan sumur resapan terdapat pada Tabel 9: 
Tabel 9. Jumlah Sumur Resapan Yang Digunakan

\begin{tabular}{cccc}
\hline $\begin{array}{c}\text { No } \\
\text { Saluran }\end{array}$ & Nama Saluran & $\begin{array}{c}\text { Luas } \\
\text { Daerah } \\
(\mathrm{Ha})\end{array}$ & $\begin{array}{c}\text { Jumlah Sumur } \\
\text { Resapan }\end{array}$ \\
\hline \multirow{2}{*}{13} & $\begin{array}{c}\text { PHB GADING } \\
\text { ELOK UTARA }\end{array}$ & 11,669 & 60 \\
33 & $\begin{array}{c}\text { PHB GADING } \\
\text { PUTIH RAYA }\end{array}$ & 19,74772 & 100 \\
35 & $\begin{array}{c}\text { PHB KELAPA } \\
\text { LILIN }\end{array}$ & 52,1146 & 261 \\
\hline
\end{tabular}

\section{KESIMPULAN DAN SARAN}

\section{Kesimpulan}

Setelah dilakukan penelitian ini ternyata dapat disimpulkan bahwa ada beberapa faktor yang menyebabkan genangan air di Kecamatan Kelapa Gading. Pertama terdapat 12 saluran drainase yang kapasitas debitnya tidak mampu menampung debit dari hujan yang terjadi pada daerah Kelapa Gading. Kedua terdapat faktor luar yang mempengaruhi kinerja dari saluran drainase sehingga menyebabkan saluran drainase tidak bekerja secara efisien atau normal. Faktor-faktor luar yang mempengaruhi saluran drainase di Kelapa Gading adalah saluran terhambat dikarenakan terhalang oleh pembangunan jalan tol yang berlangsung di daerah Kelapa Gading, kontur jalan yang menyebabkan terjadinya genangan karena air tidak mengalir, terdapat sedimentasi pada dasar saluran sehingga kapasitas saluran tidak bekerja seperti normal, dan terakhir adalah terdapat sampah dalam kuantitas yang besar sehingga menyebabkan aliran air tidak berjalan dengan lanjar atau tidak mengalir.

Solusi yang diterapkan adalah dilakukan perlebaran saluran drainase karena lebih mudah dilakukan daripada membuat sumur resapan. Untuk membuat sumur resapan biasanya tidak dapat dilakukan di dekat saluran maka harus mencari lahan kosong untuk membuat sumur resapan dan untuk mengurangi potensi banjir dibutuhkan sumur resapan yang cukup banyak per $\mathrm{km} 2$, sedangkan perdalaman saluran drainase dapat dilakukan pengurugan dasar saluran drainase.

\section{Saran}

Dari analisis saluran drainase yang dilakukan, disarankan untuk mengubah dimensi saluran yang sudah tidak mampu menampung debit dari hujan yang terjadi di daerah Kelapa Gading. Dimensi yang disarankan.

Kemudian selain disarankan untuk melakukan perubahan dimensi saluran yang tidak mampu menampung debit limpasan juga disarankan untuk melakukan normalisasi drainase.

Selain dilakukan pemeliharaan rutin terhadap saluran drainase terdapat alternatif lain untuk mengatasi genangan air yang terjadi seperti dibuat sumur resapan di setiap wilayah perumahan dan perkantoran atau ditambahkan pompa pada lokasi-lokasi yang rawan terjadi genangan air. Untuk saluran yang terdampak karena faktor luar seperti adanya pembangunan jalan maka disarankan untuk membuat saluran pengalihan supaya saluran drainase dapat mengalir dan pembuatan tampungan air sementara (kolam olakan).

\section{DAFTAR PUSTAKA}

Badan Meteorologi, Klimatologi, dan Geofisika. DKI Jakarta, 2020.

Badan Standardisasi Nasional. "SNI 2415:2016." Tata cara perhitungan debit banjir rencana (2016).

Dinas Komunikasi, Informatika dan Statistik Pemprov DKI Jakarta. Data jumlah penduduk kecamatan Kelapa Gading: Portal Resmi Provinsi DKI Jakarta. 2020. 2020.

Dinas Sumber Daya Air . Peta Saluran Drainase dan Spesifikasi Saluran. DKI Jakarta, November 2020. Kementerian Pekerjaan Umum. "Nomor 12 / PRT / M / 2014." Tata Cara Perencanaan Sistem Drainase Perkotaan. Jakarta: Kementerian Pekerjaan Umum, 2014. 63-71.

—. "Penyelenggaraan Sistem Drainase Perkotaan." 12/PRT/M/2014 (2014). 
Novika, S. Jakarta Banjir, Akses ke Mal Kena Imbasnya: finace.detik.com. 2020 Februari 08. Oktober 2020. <https://finance.detik.com/berita-ekonomi-bisnis/d-4890986/jakarta-banjir-akses-ke-malkena-imbasnya>.

Nurul Fajar Januriyadi, Yulizar,Ricky Chandra Pamungkas,Faizal Amru,Nailatul Fadhilah. "Kajian Efektivitas Sumur Resapan Dalam Mengurangi Resiko Bencana Banjir Di Kota Jakarta.” (2019).

Upono, T.C. dan R Kusumawardani. "Pemilihan Distribusi Probabilitas Pada Analisa Hujan dengan Metode Goodness of Fit Test." Jurnal Teknik Sipil dan Perencanaan, Nomor 2 Volume 18 (2016): 141-143. 